\title{
The effects of PLA biodegradable and polypropylene nonwoven crop mulches on selected components of tomato grown in the field
}

\author{
Izabela Zawiska*, Piotr Siwek \\ Department of Vegetable and Medicinal Plants \\ University of Agriculture in Krakow \\ 29 Listopada 54, 31-425 Krakow, Poland
}

\begin{abstract}
The results of two years (2010-2011) of field studies using two types of nonwoven mulches (one biodegradable, polylactic acid PLA $54 \mathrm{~g} \mathrm{~m}^{-2}$, and traditional polypropylene PP $50 \mathrm{~g} \mathrm{~m}^{-2}$ ) on the yield and quality of tomato are presented. Seeds of tomato ('Mundi' $F_{1}$ ) were sown in a greenhouse, in containers filled with perlite and sand, and then the plants at the cotyledon stage were replanted in multipot trays filled with substrate for vegetable plants. In the last week of May, seedlings were planted on mulches in the field at a spacing of $50 \times 100 \mathrm{~cm}$. The mulch was maintained throughout the growing season. A plot that remained unmulched served as the control. Tomatoes were harvested once a week. The fruits were evaluated for L-ascorbic acid, dry matter, soluble sugars and nitrate content. In 2011, the analysis of the plant material showed that the concentration of L-ascorbic acid was about $23 \%$ higher in the tomato fruits harvested from plants grown on biodegradable PLA $61 \mathrm{~g} \mathrm{~m}^{-2}$ mulch in comparison to the control. A similar effect was demonstrated for the soluble sugar concentration in 2011 for both types of nonwovens.
\end{abstract}

Key words: biodegradable nonwovens, biological value, tomato

\section{INTRODUCTION}

Mulching is a procedure used in the cultivation of many vegetable species and is one of the essential elements of the ecological cultivation of vegetables. For many years, organic materials have been used for this purpose, but mulches made from biodegradable thermoplastic polymers of plant origin, degradable under the influence of atmospheric agents or soil, are becoming more and more widespread (Auras et al. 2010). Research on the use of mulches in the cultivation of many species of plants indicates their positive impact on plant growth and yield
(Briassoulis 2007, Moreno and Moreno 2008). This effect is due to their specific interaction with the soil environment, the water and nutrients, and soil temperature (Lamont 2005). In addition, mulches prevent the compacting of the soil so that it is well aerated, which has a large impact on the rate of plant growth (Streck et al. 1995).

In Polish climatic conditions mulches are recommended mainly in thermophilic vegetable growing, i.e. for vegetables of the Cucurbitaceae family - cucumber, pumpkin, watermelon, melon and vegetables from the Solanaceae family - tomato, pepper and eggplant. Mulching can also be used on

\footnotetext{
*Corresponding author.

Tel.: +48 1266252 17; fax: +48 124111300 ;

e-mail: iza.zawiska@interia.pl (I. Zawiska).
} 
plantations of strawberries, raspberries, fruit trees and ornamental plants (Siwek and Libik 2012).

Tomato requirements in relation to soil temperature and moisture mean that mulching is very beneficial for this vegetable; tomatoes react with an acceleration of fruiting and an increase in crop yield in both ground cultivation and under covers. Black mulch is the most common in the cultivation of tomato, which inhibits weed growth in addition to affecting the temperature of the soil (Martin-Closas et al. 2002). It also affects water management by reducing water evaporation from the soil surface, allowing plants to create optimal conditions for growth (Tarara 2000, Zhang et al. 2002). This efficient water management not only saves water used for irrigation and reduces runoff into the soil profile, but also allows plants to effectively transport water in the tissues and use water vapour resources. In addition, tomatoes grown on mulches make better use of fertilizers, their growth is faster without physiological disorders and yielding occurs earlier (Moreno and Moreno 2008).

The aim of this study was to determine and compare the effects of mulches made from nonwoven biodegradable fabric and traditional polypropylene fabric on several components of the biological value of tomato in field cultivation.

\section{MATERIAL AND METHODS}

In the years 2010-2011 at the Vegetable Experimental Station of the Agricultural University in Krakow, experiments were conducted with tomato 'Mundi' $\mathrm{F}_{1}$ using two nonwovens for mulching the soil around the plants: biodegradable melt-blown (PLA $61 \mathrm{~g} \mathrm{~m}^{-2}$ ) made by the Institute of Biopolymers and Chemical Fibres and CENARO in Lodz, and a traditional nonwoven polypropylene (PP $50 \mathrm{~g} \mathrm{~m}^{-2}$ ). Tomato seeds were sown on 30.03.2010 and 31.03.2011 in a greenhouse, in sowing containers filled with perlite and sand; then at the cotyledon stage the plants were replanted in multipot trays filled with substrate for vegetable plants. In the last week of May (26.05.2010 and 24.05.2011), seedlings were planted in the field, on mulch at a spacing of $50 \times 100 \mathrm{~cm}$. The plots had an area of $7.5 \mathrm{~m}^{2}(15$ plants per plot) and were arranged in a randomised block design with four replications. The mulch was maintained throughout the growing season. Air temperature and rainfall during experiment are shown in Table 1. Harvested tomatoes were

Table 1. Air temperature and rainfall during field cultivation of 'Mundi' $F_{1}$ tomato on mulches in the years 2010-2011

\begin{tabular}{|c|c|c|c|c|c|}
\hline \multirow{2}{*}{ Month } & \multirow{2}{*}{ Ten days } & \multicolumn{2}{|c|}{ Air temperature $\left({ }^{\circ} \mathrm{C}\right)$} & \multicolumn{2}{|c|}{ Rainfall (mm) } \\
\hline & & 2010 & 2011 & 2010 & 2011 \\
\hline \multirow{3}{*}{ May } & I & 12.7 & 9.6 & 74.9 & 16.0 \\
\hline & II & 10.9 & 15.4 & 188.0 & 1.2 \\
\hline & III & 14.5 & 17.2 & 35.0 & 24.6 \\
\hline \multirow{3}{*}{ June } & I & 18.0 & 19.4 & 71.0 & 26.0 \\
\hline & II & 18.0 & 18.4 & 29.4 & 3.6 \\
\hline & III & 16.9 & 17.9 & 21.6 & 11.4 \\
\hline \multirow{3}{*}{ July } & I & 19.8 & 17.3 & 6.6 & 45.0 \\
\hline & II & 26.3 & 20.1 & 31.6 & 62.2 \\
\hline & III & 19.3 & 16.5 & 72.2 & 55.8 \\
\hline \multirow{3}{*}{ August } & I & 19.9 & 18.7 & 27.8 & 23.0 \\
\hline & II & 19.6 & 19.2 & 38.0 & 5.8 \\
\hline & III & 16.9 & 20.3 & 72.4 & 8.4 \\
\hline \multirow{3}{*}{ September } & I & 11.7 & 16.5 & 53.2 & 8.4 \\
\hline & II & 13.4 & 15.8 & 9.8 & 8.6 \\
\hline & III & 12.1 & 14.2 & 29.4 & 1.4 \\
\hline \multicolumn{6}{|c|}{ Mean/sum per month } \\
\hline May & & 12.7 & 14.1 & 297.9 & 41.8 \\
\hline June & & 17.6 & 18.5 & 122.0 & 41.0 \\
\hline July & & 21.8 & 17.9 & 110.4 & 163.0 \\
\hline August & & 18.8 & 19.4 & 138.2 & 37.2 \\
\hline September & & 12.4 & 15.5 & 92.4 & 18.4 \\
\hline
\end{tabular}


Table 2. Transmittance, absorbance and reflectance of new nonwoven biodegradable and polypropylene crop mulches in the range 400-700 $\mathrm{nm}$ (PAR) and 700-1100 nm

\begin{tabular}{lccc}
\hline Mulch & Transmittance & $\begin{array}{c}\text { Absorbance } \\
(\%)\end{array}$ & Reflectance \\
\hline PLA $\left(61 \mathrm{~g} \mathrm{~m}^{-2}\right)$ & 22.6 & 73.6 & 3.8 \\
$\operatorname{PP}\left(50 \mathrm{~g} \mathrm{~m}^{-2}\right)$ & 8.0 & 86.8 & 5.2 \\
\hline
\end{tabular}

subjected to laboratory analysis. L-ascorbic acid (mg \%) was determined using the Tillmans method (Tillmans et al. 1932). In order to determine dry matter content (\%), samples of plant material were dried at $70^{\circ} \mathrm{C}$. Soluble sugars $(\%$ d.w.) were estimated using the anthrone method (Yemm and Wills 1954) and nitrate ions ( $\mathrm{mg} \mathrm{NO}_{3}{ }^{-} \mathrm{kg}$ d.w.) using ORION ion-selective electrodes together with a UNICAM-9460 ionometer.

The results of the experiment were subjected to univariate analysis as an independent system. Significance of differences was determined by the Tukey HSD test. All calculations were performed at a given significance level of $p=0.05$. Statistica 9 software was used for the calculations.

\section{RESULTS AND DISCUSSION}

The experiment demonstrated that covering the soil with the two different types of mulches resulted in significant changes in the environmental conditions in which the plants were grown. The spectral properties of the nonwoven mulches (Tab. 2) impinge directly on the thermal conditions of the soil and the air surrounding the plants. As indicated by Ham et al. (1993), an increase in soil temperature depends on the heating of mulches by direct sunlight. These relationships have been confirmed by many studies in Polish and foreign publications (Candido et al. 2003, Błażewicz-Woźniak 2010). In this experiment comparing mulches made of various polymers, nonwoven PP $50 \mathrm{~g} \mathrm{~m}^{-2}$ heated the soil better than PLA $61 \mathrm{~g} \mathrm{~m}^{-2}$. This should be linked to the very high, almost $100 \%$ absorption rate of radiation by the former fabric.

Available literature sources indicate a positive effect of mulches on the yield of the vegetable crops and their biological value. The presented experiment demonstrated that the content of L-ascorbic acid in tomato fruit was on the level of 17.13 to $25.10 \mathrm{mg}$ $100^{-1} \mathrm{~g}$ d.w., and did not differ from the average of this component for tomatoes (Tab. 3). In 2011, the analysis of the plant material for the content of this component showed that it was about $23 \%$ higher in the tomato fruits harvested from plants where the applied mulch was biodegradable PLA $61 \mathrm{~g}$ $\mathrm{m}^{-2}$ nonwoven fabric in comparison to the control. Similar results were obtained by Rekowska (2011), who showed that the content of L-ascorbic in lettuce harvested from plots mulched with black nonwoven polypropylene was higher than the content of plants collected from the control. Majkowska-Gadomska et al. (2012) showed that mulches (PE and PP) did not significantly affect the content of L-ascorbic. In

Table 3. The effect of kind of mulch used on L-ascorbic acid, dry matter, soluble sugar and nitrates content in 'Mundi' $\mathrm{F}_{1}$ tomato fruit

\begin{tabular}{llccc}
\hline Component & Mulch & 2010 & 2011 & Mean \\
\hline \multirow{2}{*}{ L-ascorbic acid (mg $100 \mathrm{~g}^{-1}$ f.w.) } & PLA $\left(61 \mathrm{~g} \mathrm{~m}^{-2}\right)$ & $17.81 \mathrm{ab}$ & $24.23 \mathrm{a}$ & $21.02 \mathrm{~B}$ \\
& PP $\left(50 \mathrm{~g} \mathrm{~m}^{-2}\right)$ & $17.13 \mathrm{a}$ & $25.10 \mathrm{~b}$ & $21.11 \mathrm{~B}$ \\
& Control $($ without mulch) & $18.66 \mathrm{~b}$ & $19.66 \mathrm{~b}$ & $19.16 \mathrm{~A}$ \\
\hline \multirow{3}{*}{ Soluble sugars (\%) } & PLA $\left(61 \mathrm{~g} \mathrm{~m}^{-2}\right)$ & $2.06 \mathrm{~b}$ & $2.96 \mathrm{~b}$ & $2.51 \mathrm{~B}$ \\
& PP $\left(50 \mathrm{~g} \mathrm{~m}^{-2}\right)$ & $1.88 \mathrm{a}$ & $3.20 \mathrm{~b}$ & $2.54 \mathrm{~B}$ \\
& Control $($ without mulch) & $2.10 \mathrm{~b}$ & $2.62 \mathrm{a}$ & $2.36 \mathrm{~A}$ \\
\hline \multirow{3}{*}{ Dry matter (\%) } & PLA $\left(61 \mathrm{~g} \mathrm{~m}^{-2}\right)$ & $5.38 \mathrm{a}$ & $6.40 \mathrm{a}$ & $5.89 \mathrm{~B}$ \\
& PP $\left(50 \mathrm{~g} \mathrm{~m}^{-2}\right)$ & $5.17 \mathrm{a}$ & $6.96 \mathrm{~b}$ & $6.06 \mathrm{C}$ \\
& Control (without mulch) & $5.46 \mathrm{a}$ & $6.05 \mathrm{a}$ & $5.75 \mathrm{~A}$ \\
\hline \multirow{2}{*}{ Nitrates $\mathrm{NO}_{3}^{-}$(mg kg-1 f.w.) } & PLA $\left(61 \mathrm{~g} \mathrm{~m}^{-2}\right)$ & $28.31 \mathrm{~b}$ & $19.46 \mathrm{~b}$ & $23.88 \mathrm{~A}$ \\
& PP $\left(50 \mathrm{~g} \mathrm{~m}^{-2}\right)$ & $32.98 \mathrm{a}$ & $20.46 \mathrm{~b}$ & $26.22 \mathrm{~B}$ \\
& Control (without mulch) & $26.89 \mathrm{a}$ & $17.99 \mathrm{a}$ & $22.44 \mathrm{C}$ \\
\hline
\end{tabular}

Values marked with the same lowercase and uppercase letters do not differ significantly at $p=0.05$ 
turn, Adamczewska-Sowińska and Kołota (2010) showed a $16-23 \%$ higher content of L-ascorbic acid in fruits of eggplant harvested from the control (without mulches). Wojciechowska et al. (2007) also found significantly lower (20.5\%) L-ascorbic acid in the heads of butterhead lettuce from plants mulched with black polyethylene film compared to the control. Similar results were found in the present experiment in 2010.

In 2011, the use of nonwoven fabric resulted in an increased concentration of soluble sugars in the fruit. A similar dependence was reported by Kosterna et al. (2010), who showed that the concentrations of soluble sugars from fruits of melon plants on black polyethylene film mulch and black nonwoven polypropylene mulch were $21 \%$ and $12 \%$ higher, respectively, than the content in fruits from the control. In turn, Wojciechowska et al. (2007) showed a greater concentration of sugars in the heads of butterhead lettuce harvested from plots without mulches than plots mulched with polyethylene foil. Sugars are a large proportion of the percentage of dry matter. Hence, the dynamics of changes in the amount of this component largely coincided with changes in the level of sugars. The cultivation of tomatoes on mulches resulted in a significant effect of nonwovens on this attribute. An especially beneficial effect was found using PP $50 \mathrm{~g} \mathrm{~m}^{-2}$ nonwoven fabric mulching in 2011. Similar results were demonstrated by Dyduch and Najda (2005) in experiments with the cultivation of celery. They determined larger amounts of dry matter in the petioles of plants grown with the use of mulches made from polyethylene films. In turn, in experiments with the cultivation of melons using polyethylene and polypropylene mulches, Kosterna et al. (2010) showed that a higher content of dry matter was found in fruits gathered from the control. A similar pattern was noted in the first year of the present experiment.

The level of nitrate ions in some species of vegetables can be very high, but fruits have a low tendency to accumulate nitrate (Bao-Ming Chena et al. 2004). In this experiment, there were no cases where nitrate content exceeded the maximum acceptable doses defined in the Regulations of the Ministry of Health (EC 2005). The highest nitrate content of all of the combinations was $32.98 \mathrm{mg}$ $\mathrm{NO}_{3}$ - dry weight. We conclude that a significantly higher content of nitrate ions was found under any of the mulching treatments in both years of the experiment. These results are comparable to those of Benoit and Ceustermans (1992). In their experiments on soil mulching with black plastic, they found significantly higher levels of nitrates in lettuce grown on the mulches than those without. In the cultivation of lettuce, Wierzbicka (2001) also showed a negative impact on the nitrate content under mulching. A reduced concentration was found in the fruits of plants from the control. Similarly, Wojciechowska et al. (2007) showed that black mulch made of PE film increased nitrate ion content in celery petioles. This relationship most likely resulted from a lack of competition for nitrogen between the crop and weeds, which did not develop under black mulches (Blackshaw and Brandt 2008).

\section{ACKNOWLEDGEMENTS}

The research was supported by a project grant from the Polish Ministry of Science and Higher Education - PBZ-MNiSW - 01/II/2007.

\section{CONCLUSIONS}

1. The use of nonwoven polypropylene PP $50 \mathrm{~g} \mathrm{~m}^{-2}$ mulch resulted in obtaining fruit with a higher content of L-ascorbic acid.

2. The use of nonwoven biodegradable PLA 61 $\mathrm{g} \mathrm{m}^{-2}$ as mulch resulted in fruits with a higher content of soluble sugars and dry matter and a smaller concentration of nitrate ions than in the control

\section{REFERENCES}

Adamczewska-Sowińska K., KoŁota E., 2010. Yielding and nutritive value of field cultivated eggplant with the use of living and synthetic mulches. Acta Sci. Pol., Hortorum Cultus 9(3): 191-199.

Auras R., Lim L., Selke S., Tsuji H., 2010, Poly(Lactic Acid): Synthesis, Structures, Properties, Processing, and Applications, Wiley \& Sons, Inc.

Bao-Ming Chena, Zhao-Hui Wangb, Sheng-Xiu Lib, Gen-Xuan Wanga, Hai-Xing Songc, Xi-Na Wangb., 2004. Effects of nitrate supply on plant growth, nitrate accumulation, metabolic nitrate concentration and nitrate reductase activity in three leafy vegetables. Plant Sci. 167: 635-643.

Benoit F., Ceustermans N., 1992. Ecological vegetable growing with plastics. Plasticulture 95(3): 11-20.

BlaCKSHAW R.E, BRANDT R.N., 2008. Nitrogen fertilizer rate effects on weed competitiveness is species dependent. Weed Sci. 56(5):743-747.

BŁAżewicz-WoźNiaK M., 2010. Effect of soil land plant covering as well as sewing term upon fennel bulb nutritional value. Acta Sci. Pol., Hortorum Cultus 9(1): 3-12. 
Briassoulis D., 2007. Analysis of the mechanical and degradation performances of optimized agricultural biodegradable films. Polym. Degrad. Stab. 92: 11151132.

Candido V., Miccolis V., Gatta G., Margiota S., MANERA C., 2003. Innovative films for mulching in protected cultivation. Acta Hort. 614: 379-386.

Dyduch J., NAJdA A., 2005. Zmiany zawartości suchej masy i kwasu L - askorbinowego w liściach roślin dwóch odmian selera naciowego w zależności od wieku zbieranych roślin i ściółkowania gleby. Zesz. Nauk. AR we Wrocławiu 515: 111-119 [in Polish with English summary].

EC (COMMISSION REGULATION), 2005. No $1822 / 2005$ of 8 November 2005 amending Regulation (EC) No $466 / 2001$ as regards nitrate in certain vegetables.

Ham J.M., Kluitenberg G.J., Lamont W.J., 1993. Optical properties of plastic mulch affect the field temperature regime. J. Amer. Soc. Hort. Sci. 118(2): 188-193.

Kosterna E., Zaniewicz-Bajkowska A., Rosa R., Franczuk J., Borysiak-MarciniaK I., Chromińska., 2010. Effect of black synthetic mulches on the fruit quality and selected components of nutritive value of melon Acta Sci. Pol., Hortorum Cultus 9(3): 27-36.

LAMONT W.J., 2005. Plastics: Modifying the microclimate for the production of vegetable crops. Hort. Technology 15(3): 477-481.

Majkowska-Gadomska J., WierzBicka B., Arcichowska K., 2012. Yield and quality of tomato (Lycopersicon esculentum Mill.) fruit harvested from plants grown in mulched soil. Acta Agrobot. 65(4): 149-156.

Martin-Closas L., Soler J., Pelacho A.M., 2002. Effect of different biodegradable mulch materials on an organic tomato production system. Biodegradable Materials and Natural Fiber Composites. KTBL. Dramstadt. Schrift 414: 78-85.
Moreno M.M., Moreno A., 2008. Effect of different biodegradable and polyethylene mulches on soil properties and production in a tomato crop. Sci. Hort. 116: 256-263.

REKOWSKa E., 2011. The effect of soil and plants covering with the polypropylene nonwoven on the quantity and quality of yield of stem lettuce (Lactuca sativa L. var. augustana Irish). Acta Sci. Pol., Hortorum Cultus 10(1): 3-11.

SiweK P., Libik A., 2012. Plastic covers in polish horticulture. Plasticulture 131: 65-73.

Streck N.A., Schneider F.M., Buriol G.A., Heldwein A.B., 1995. Effect of polyethylene mulches on soil temperature and tomato yield in plastic greenhouse. Sci. Agric. Piracicaba 52(3): 587-593.

TARARA J.M., 2000. Microclimate modification with plastic mulch. HortScience 35: 169-180.

Tillmans J., Hirsch P., Hirsch W.Z., 1932. The reducing property of plant foods and its relation to vitamin C. Z. Untersuch. Lebensmitt. 63(1).

WierzBicka B., 2001. The effect of cultivation methods and cultivar on yield and chemical composition of lettuce in field culture. Hort. Veg. Grow. 22(4): 112-119.

Wojciechowska R., Siwek P., Libik A., 2007. Effect of mulching with various films on the yield quality of butterhead lettuce and celery stalks with special reference to nitrate metabolism. Folia Hort. 19(1): 37-44.

Yemm E.W., Wills A.J., 1954. The estimation of carbohydrates in plant extracts by anthrone. Biochem. J. 58: 508-514.

Zhang Ke-Li, Yuan Liang-Jie, Xi Mei-Yun, Yu YouZu, Sun Ju-TAng., 2002. The application of lightsconversed polyethylene film for agriculture. Wuhan University Journal of Natural Sciences 7(3): 365-367.

Received September 23, 2014; accepted December 3, 2014 